\title{
Soil indicators to assess the effectiveness of restoration strategies in dryland ecosystems
}

\author{
Edoardo A. C. Costantini ${ }^{1}$, Cristina Branquinho ${ }^{2}$, Alice Nunes ${ }^{2}$, Gudrun Schwilch ${ }^{3}$, Ilan Stavi ${ }^{4}$, \\ Alejandro Valdecantos ${ }^{5}$, and Claudio Zucca ${ }^{6}$ \\ ${ }^{1}$ Consiglio per la ricerca in agricoltura e l'analisi dell'economia agraria, Agrobiology and Pedology \\ Research Centre, Firenze, Italy \\ ${ }^{2}$ Centre for Ecology, Evolution and Environmental changes, Faculdade de Ciências da Universidade de Lisboa, \\ Campo Grande, Lisbon, Portugal \\ ${ }^{3}$ Centre for Development and Environment (CDE), University of Bern, Bern, Switzerland \\ ${ }^{4}$ Dead Sea and Arava Science Center, Yotvata 88820, Israel \\ ${ }^{5}$ Centro de Estudios Ambientales del Mediterráneo (CEAM), Valencia, Spain and Dep. Ecologia, \\ Universidad de Alicante, Alicante, Spain \\ ${ }^{6}$ International Center for Agricultural Research in the Dry Areas (ICARDA), Amman, Jordan and Dipartimento \\ di Agraria \& Desertification Research Centre (NRD), University of Sassari, Sassari, Italy
}

Correspondence to: Edoardo A. C. Costantini (edoardo.costantini@crea.gov.it)

Received: 24 November 2015 - Published in Solid Earth Discuss.: 8 December 2015

Revised: 25 February 2016 - Accepted: 25 February 2016 - Published: 10 March 2016

\begin{abstract}
Soil indicators may be used for assessing both land suitability for restoration and the effectiveness of restoration strategies in restoring ecosystem functioning and services. In this review paper, several soil indicators, which can be used to assess the effectiveness of ecological restoration strategies in dryland ecosystems at different spatial and temporal scales, are discussed. The selected indicators represent the different viewpoints of pedology, ecology, hydrology, and land management. Two overall outcomes stem from the review. (i) The success of restoration projects relies on a proper understanding of their ecology, namely the relationships between soil, plants, hydrology, climate, and land management at different scales, which are particularly complex due to the heterogeneous pattern of ecosystems functioning in drylands. (ii) The selection of the most suitable soil indicators follows a clear identification of the different and sometimes competing ecosystem services that the project is aimed at restoring.
\end{abstract}

\section{Introduction}

Restoring degraded drylands is a worldwide issue. The "land degradation neutrality" target promoted by the United Nations Convention to Combat Desertification (UNCCD) indicates that the progress made with restoration could compensate the impacts of degradation, stressing the importance of a quantitative evaluation process. Studies and attempts to implement restoration strategies in different dry environments are numerous, from rangelands to shrub and forest stands (Camprubi et al., 2015; Cortina et al., 2009; Fuentes et al., 2010; Roa-Fuentes et al., 2015; Zucca et al., 2015a, b), from agricultural ecosystems to mining sites and brownfields (Dickinson et al., 2005; de Moraes Sá et al., 2015; Hasanuzzaman et al., 2014; Oliveira et al., 2011; Stroosnijder, 2009; Toktar et al., 2016; Wong et al., 2015). Though restoring degraded drylands is also a complex issue, it can be pursued by means of several strategies, all of which consider soil characteristics, either directly or indirectly. In fact, soil is a key part of the Earth system, as it controls the hydrological, erosional, biological, and geochemical cycles (Brevik et al., 2015; Keesstra et al., 2012; Smith et al., 2015). If soilinherent slow-changing soil qualities are of utmost impor- 
tance in designing ecological restoration strategies, soil dynamic properties can be used to monitor and assess the consequences of restoration activities on ecosystem functioning and services. In any case, finding suitable indicators to monitor ecological restoration activities at different scales, both within ecosystems and in the broader socioeconomic system, requires a full understanding of soil-plant-ecosystem relationships, as well as an interdisciplinary and integrative approach. The integration of different viewpoints from complementary disciplines is, nevertheless, still uncommon in restoration. Drylands' restoration, in particular, due to their idiosyncratic characteristics of high spatial heterogeneity and temporal variability, represents an even greater challenge, requiring restoration indicators able to reflect different spatial and temporal variations.

The objective of this review is to present and discuss soil indicators which show potential to check the effectiveness of restoration activities in drylands at different spatial and temporal scales. The subject is treated from the viewpoints of specialists coming from different disciplines, namely pedology, ecology, hydrology, and land management, all dealing with the practice of ecosystems' restoration. The paper is presented in three parts. The first part introduces linkages between land degradation and ecological restoration, stressing specificities of dryland ecosystems; the second part deals with soil indices and indicators to be used before and after restoration at different scales, and their relationship with soil processes; the third part addresses more integrated assessment of restoration, linking soil and ecological issues with socioeconomic perception. In particular, the paper introduces the purpose of restoration in drylands in Sect. 1.1 and addresses key interactions between plants, soil, and climate in Sects. 2 and 3; having these interactions in mind, a series of soil indicators are discussed from local scale (Sect. 4) to landscape scale (Sects. 5 and 6). More specifically, the nature of soil indicators covers the physical (Sect. 4.1), chemical (Sect. 4.2), biochemical, and biological aspects (Sects. 4.3, 4.4 and 4.5 ), its integration in a landscape functional approach (Sect. 5), and in a holistic assessment, which also considers socioeconomic indicators (Sect. 6).

\section{Restoration of ecosystem services in drylands}

Land degradation is related to the loss of ecosystem services and is referred to as desertification when it occurs in drylands. Desertification is considered a process leading to a final stage of land degradation, implying the loss of sustainable provisioning services such as agricultural and forestry productivity. This loss can be irreversible, or have very little chance of reversibility without external inputs, leading to a status of "functional sterility" (Costantini et al., 2009b).

A wide range of options are available for restoring the ecosystem services in degraded lands. Strategies intended to enhance ecosystem functions form a continuum of options that can be broadly classified as prevention, mitigation, and

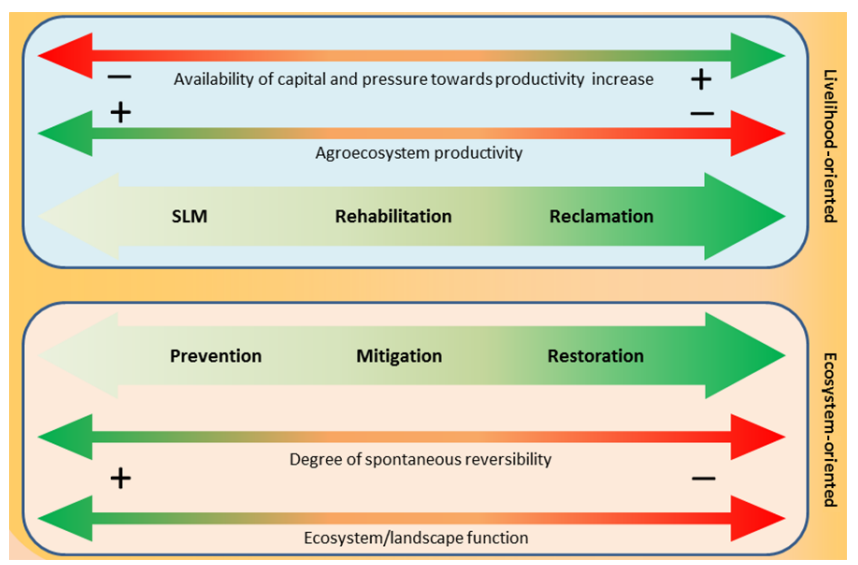

Figure 1. Soil restoration strategies, either livelihood- or ecosystem-oriented.

restoration interventions, if considered from an ecological perspective (Zucca et al., 2013a). On the other hand, agroecosystems in drylands are often affected by complex and interlinked socioeconomic and environmental drivers that determine reduced farm yields and community income. The interventions carried out in these situations are more commonly aimed at improving livelihoods and at conserving or enhancing the biological and economic productivity of the land. In these cases, terms such as sustainable land management (SLM), rehabilitation, and reclamation are preferred for indicating increasing intervention intensities (Fig. 1).

Considering the range of options available, optimal choices depend on the restoration objectives, on the timeline (e.g., short-term versus long-term achievement), on the specificities of the context or landscape to be restored, and on the evaluation of trade-offs (i.e., different options will affect different concerned ecosystem services in different ways, such as plant productivity, soil carbon sequestration, and biodiversity). However, while passive restoration activities could be effective under relatively moderate degraded conditions (e.g., removing disturbance factors), active approaches may be necessary in more heavily degraded or stressed environments. One example of passive restoration techniques is stopping grazing in overgrazed rangelands or leaving fallow intensively managed croplands. This has proved to be effective over the long term, although certain risks may threaten recovery, such as wildfires or the spread of invasive species. On the other hand, active restoration activities may require interventions such as plant introduction, with utilization of resources that are often limited, such as human labor, machinery, chemical products, and tree planting. Acting on vegetation is the most common approach in land restoration. By regulating a range of hydrologic, geomorphic, aeolian, pedogenetic, and biotic processes at micro, patch, and hillslope scales, plants increase ecosystem health through their productivity and diversity. Due to limited water availability, the restoration of degraded drylands is more challenging than 
lands under more humid environments. It is therefore reasonable that restoration efforts in drylands by planting would primarily work to increase rooting depth and soil volume, in order to increase soil water storage and availability.

Drylands are water-limited environments, where evaporative demands are not compensated by moisture inputs through precipitation, and biomass production is constrained. In general, the lower the precipitation, the higher the bare soil occurrence between shrubs and herbaceous plants. Nonetheless, the relationships between precipitation rates and vegetation cover may not be linear (Hirota et al., 2011). The frequency of intermediate states between forest, grassland, and savannahs is small, highlighting the occurrence of tipping points where ecosystems can shift from one physiognomic state to the other. The different vegetation physiognomies of drylands (e.g., shrublands, grasslands) have different demands of soil water and nutrients, and different soil depths at which roots uptake water.

Spatial heterogeneity is another important feature of drylands. In arid areas, plant spatial distribution is generally patchy and more influenced by local soil conditions and slope aspect than in humid areas (Príncipe et al., 2014). The spatial pattern of vegetation causes discontinuities in biomass production, affects soil fertility, and interacts with trophic chains, including soil microorganisms and rate of decomposition. This spatial heterogeneity gives origin to the so-called "islands of fertility", where soil and water resources, coupled with improved microclimatic conditions, may facilitate the establishment of other plant species underneath the canopy of trees or shrubs.

Drylands are also characterized by a high seasonal and interannual climatic variability, resulting in a highly variable distribution of precipitation over time. This temporal variability, along with soil characteristics (e.g., soil-waterholding capacity), determines how much water is available to plants and for how long, influencing vegetation structure and cover. Disturbance dynamics, such as livestock management, shrub clearing, or deforestation also greatly affect plant cover and vegetation structure.

\section{Plant-soil key interactions}

The success of vegetation establishment in restoration projects of degraded drylands largely depends on the extensive understanding of the relationships between soil characteristics and plant-rooting features. Globally, the soil depth at which different plant growth forms absorb water varies considerably (Canadell et al., 1996). In water-limited ecosystems, root systems' mean depths increase with above ground size: annuals $<$ perennial forbs and grasses $<$ dwarf shrubs $<$ shrubs $<$ trees (Table 1, Fig. 2). Stem succulents are as shallowly rooted as annuals, but have relatively high lateral root spreads (Schenk and Jackson, 2002a). Hence, soil properties that determine water availability along the soil profile largely determine the type of vegetation with potential for establishment. For instance, savannah-like systems of holm oak (Quercus ilex L.) and cork oak (Quercus suber L.) woodlands, found in western Mediterranean Basin drylands, have a grassy understory dominated by annuals, with most of the roots concentrated in the upper $20-30 \mathrm{~cm}$ of the soil. In general, this upper layer includes organic soil horizons, where the overall root density is highest, most likely because it stores nutrients and has higher water-holding capacity. However, grassland areas are often intermingled with shrub patches, which evidently obtain water from deeper soil layers. Some of the most prominent shrubs in these systems are the shallow-rooting $(30-40 \mathrm{~cm})$ rockroses (Cistaceae family), which have a high lateral root spread. Such root systems may improve water-use efficiency. When soils are deeper, shallow-rooted shrubs may coexist with deeper rooting plants such as the strawberry tree (Arbutus unedo L.) or the mastic tree (Pistacia lentiscus L.) that may get water lower than $2 \mathrm{~m}$ (Silva et al., 2002). Deep roots play a fundamental role during the dry season, because they reach deeper layers where water depletion is not as widespread as at the surface. In fact, the dominant oak trees in Mediterranean woodlands seem to get water from even deeper depths (groundwater), particularly during the dry season (Kurz-Besson et al., 2006). Another example is the Ibero-North African dryland steppe, dominated by the perennial alpha grass (Stipa tenacissima L.). Its root system goes no further than $50 \mathrm{~cm}$ depth (Cortina et al., 2009), somewhat similar to the aforementioned shallow-rooting shrubs, enabling the species to access upper soil layers after small rainfall events. In these environments, biological soil crusts are a prominent feature covering bare soil. They play an important role by protecting soil surface from wind and water erosion, participating in nutrient cycling, reducing loss of water due to evaporation, and taking part in biotic interactions (e.g., influencing seed germination of vascular plants) (Bowker et al., 2014). Biological soil crusts have been introduced in deserts in several parts of the world in order to help prevent erosion and desertification (e.g., USA, China, Israel).

Soil heterogeneity is reflected in water distribution and availability for root uptake along the soil profile. The major factors affecting this distribution are soil particle size and seasonality of precipitation. Water-limited ecosystems tend to have deeper root systems in coarse-textured soils than in fine-textured soils, because the former have lower water-holding capacity and water tends to percolate more deeply, where groundwater, or a temporary perched water table, may be present. Conversely, the existence of a restrictive soil layer, for instance, in soils with a compacted or cemented layer, or high clay content in the subsoil, or showing shrinkswell properties (Vertisols) may favor shallow-rooted herbs, while limiting the establishment of deeper-rooted species, like perennial grasses or shrubs. Soil information concerning water availability of the different soil horizons, and not only of topsoil, is thus very important in order to adequately 
Table 1. Absolute root dimensions (geometric means) for maximum rooting depths and lateral root spreads for seven plant growth forms in water-limited ecosystems worldwide. Geometric means marked by different letters are significantly different at $p<0.05$ according to one-way ANOVA (analysis of variance) (adapted from Schenk and Jackson, 2002a).

\begin{tabular}{lrrr|rrr}
\hline & \multicolumn{3}{c|}{ Rooting depths (m) } & \multicolumn{3}{c}{ Lateral root spreads (m) } \\
\cline { 2 - 7 } & \multicolumn{1}{r}{$\begin{array}{r}\text { Geometric } \\
\text { mean }\end{array}$} & $\begin{array}{r}\text { 95 confidence } \\
\text { interval for } \\
\text { geometric mean }\end{array}$ & $n$ & $\begin{array}{r}\text { Geometric } \\
\text { mean }\end{array}$ & $\begin{array}{r}\text { 95 \% confidence } \\
\text { interval for } \\
\text { geometric mean }\end{array}$ \\
\hline Trees & 76 & $3.27 \mathrm{a}$ & $2.54-4.08$ & 40 & $7.67 \mathrm{a}$ & $5.11-9.88$ \\
Shrubs & 156 & $2.14 \mathrm{~b}$ & $1.87-2.42$ & 119 & $2.20 \mathrm{~b}$ & $1.79-2.65$ \\
Dwarf shrubs & 305 & $1.27 \mathrm{c}$ & $1.16-1.38$ & 227 & $0.64 \mathrm{c}$ & $0.56-0.72$ \\
Perenn. grasses & 271 & $1.04 \mathrm{~d}$ & $0.96-1.12$ & 168 & $0.34 \mathrm{~d}$ & $0.30-0.38$ \\
Perenn. forbs & 330 & $1.05 \mathrm{~d}$ & $0.95-1.15$ & 270 & $0.30 \mathrm{~d}$ & $0.27-0.34$ \\
Annuals & 123 & $0.38 \mathrm{e}$ & $0.32-0.46$ & 109 & $0.12 \mathrm{e}$ & $0.09-0.14$ \\
Succulents & 43 & $0.28 \mathrm{e}$ & $0.21-0.35$ & 32 & $1.37 \mathrm{~b}$ & $0.84-2.02$ \\
\hline
\end{tabular}

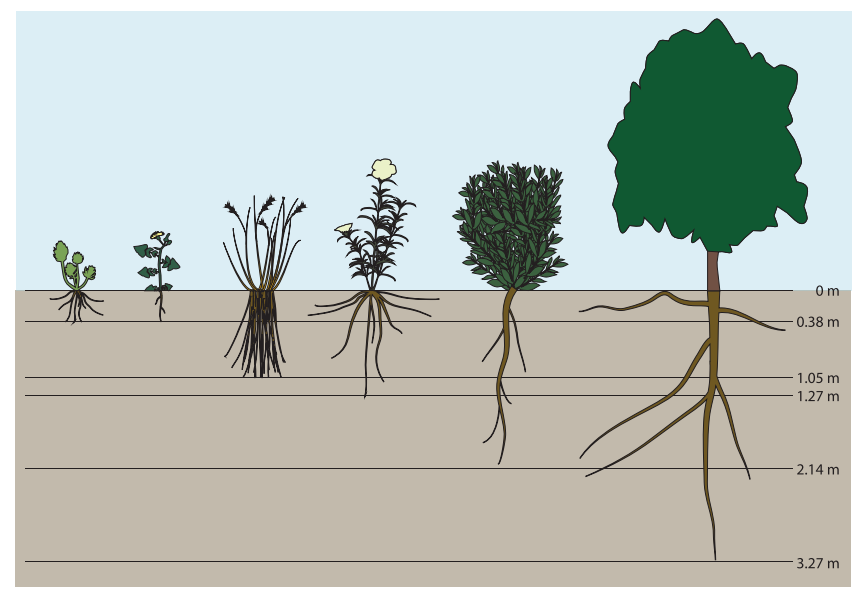

Figure 2. Rooting depths illustrated as schematic drawings of individual plants using approximate geometric mean values for six growth form categories (from left to right): succulents, annual herbs, perennial herbs, dwarf shrubs, shrubs, and trees. Root depths' means were retrieved from Schenk and Jackson (2002a).

select the actions and species used to restore plant cover of degraded sites.

The residence time of water in soil, i.e., the period during which water remains available at a certain soil layer after a precipitation event, is particularly important for plant communities in water-limited ecosystems, especially during the growing season. The longer the period during which water is available, the greater the opportunity for plants to survive, grow, and reproduce. In general, if water is retained in the uppermost soil layers, that may be beneficial for shallowrooting herbaceous species germination and establishment. On the other hand, if water percolates rapidly to deeper layers, that may favor woody vegetation.

Precipitation distribution and seasonality, i.e., if precipitation is evenly distributed throughout the year or occurs during the cold or warm seasons of the year, play a key role re- garding water availability for plants along the soil profile. In drylands, shrubs are more shallowly rooted in climates with summer than winter precipitation regimes (Schenk and Jackson, 2002b). This is because in climates with summer precipitation, the residence time of water in the soil is shorter, and a wider and shallower root system is better able to uptake water before it evaporates. Succulent species are good examples, since they are in general as shallowly rooted as annuals, but have denser lateral root systems, similar to shrubs. These life forms become very widespread when low precipitation amounts are coupled with high temperatures, and hence water residence time is very short.

The assessment of water residence time in soils, and in particular, the information about when and for how long soil water is available to plants, is thus of major importance to predict the most suitable type of plant community for a given site.

\section{The interaction between climatic aridity and soil characteristics: the soil aridity index}

The aridity index (rainfall/evapotranspiration ratio, AI) has been taken by the United Nations Convention to Combat Desertification (UNCCD) as a reference for the definition of the areas subjected to desertification. The usefulness of the AI relies upon the relative ease it can be calculated from standard climatic data. However, the AI has several drawbacks. For example, it does not take into account the capacity of the soil to regulate water availability, deep drainage, and runoff, which can vary noticeably inside the same climatic region. This is particularly true in transitional ecozones, such as in the Mediterranean Basin that is characterized by a notable pedodiversity (Ibáñez et al., 2013) and where lands at high and low risk of desertification are very often finely intermingled (Costantini et al., 2009b).

Pedoclimate, that is soil moisture and temperature regimes, has also been used to characterize areas with a cer- 
tain desertification risk (Eswaran and Reich, 1998). Indeed, the American Soil Taxonomy considers soil moisture regime based on a yearly assessment of the number of days in which the soil moisture control section ${ }^{1}$ is either moist, partially dry, or completely dry, while soil temperature regime classification refers to mean annual temperature at $50 \mathrm{~cm}$ depth (Soil Survey Staff, 1999). Pedoclimate can be used as an indicator of inherent soil quality at different geographic scales. On a broader level, soil moisture and temperature regimes are used to delineate the areas at potential risk of desertification. In particular, the aridic, xeric, dry xeric, and ustic soil moisture regimes refer to areas with varying degrees of potential water deficit, while soils with thermic and hyperthermic temperature regimes refer to lands with high temperatures in the root zone. At a more detailed level, the soil aridity index (SAI) was calculated as the average cumulative days per year when the soil moisture control section was completely dry (number of days with dry soil) (Costantini et al., 2009a). The SAI was specifically aimed at highlighting the differences in pedoclimate that may result from the rather detailed combinations of shallow soils, or with limited available water capacity. This value was estimated using software based on the Erosion/Productivity Index Calculator (EPIC) model. The SAI was related to easily available climatic and soil data through a multiple regression, linking the SAI value to longterm mean annual air temperature, total annual rainfall, and soil available water content. The SAI showed a good correlation with the $\mathrm{AI}$ and with the vegetation vigor and soil cover classes of natural and natural-like areas. In addition, the SAI highlighted a more consistent correlation with the Normalized Difference Vegetation Index (NDVI) class distribution than the AI (Costantini et al., 2009b). Being influenced by both soil and climate variations, the SAI is particularly useful in highlighting vulnerable lands where increased rainfall deficit and enhanced soil erosion could lead to desertification. The use of the SAI at detailed scales could be improved by adding the influence of local morphology on runoff and subsurface water flows.

\section{Soil indicators}

Ecosystem services are determined by soil properties and their assessment requires the use of selected indicators (Calzolari et al., 2016). A wide range of soil indicators may be used, depending on the purpose and scale of evaluation. In restoration planning, soil indicators are needed to support both the design and monitoring phases. However, different information is needed for these two purposes. The design phase mainly requires information about soil (and site) attributes that may affect the probability of success of the in-

\footnotetext{
${ }^{1}$ The soil moisture control section is the layer in-between the depth to which a dry soil will be wetted by $2.5 \mathrm{~cm}$ of precipitation in a $24 \mathrm{~h}$ period and the depth to which the same soil will be wetted by $7.5 \mathrm{~cm}$ of precipitation in the same period.
}

tervention. The input properties used to work the indicators can be both inherent characteristics (De la Rosa and Sobral, 2008) such as topographic slope angle and aspect, surface rockiness, soil depth, texture, stoniness, structure, presence of subsoil pans, and subsoil wetness conditions, or more dynamic attributes such as acidity and salinity. Planning can be supported by the identification of "optimal" ranges of values of such variables that increase chances of success of restoration and/or decrease risks and costs, and this can be done by means of land suitability schemes. Several approaches are available to create indicators, ranging from traditional categorical or parametric schemes (Costantini, 2009) to more complex approaches integrating multicriteria analysis and decision support frameworks (Yi and Wang, 2013; Uribe et al., 2014).

The soil information needed to monitor and assess restoration depends on the time and spatial scales. In the short term, it might be important to focus on dynamic properties such as soil organic matter, $\mathrm{pH}$, available phosphorus, nitrogen, and other nutrients, and macroporosity. However, because of the large spatial and temporal variability of ecosystems, particularly in drylands, it is critical that indicators focus on "slow variables" (Carpenter and Turner, 2000) so that the assessment of long-term changes and of the sustainability of land management is not confused by short-term variations in land and socioeconomic conditions (Salvati and Baiocco, 2011; Zucca et al., 2013a). Slow indicators can more directly reflect impacts on inherent soil qualities, e.g., through improved structure and porosity and increased topsoil depth and water-holding capacity. Table 2 shows a list of the most frequently used soil indicators, specifying their functional relevance.

\subsection{Physical and hydrological soil indicators}

In drylands, the most important soil indicators refer to the factors regulating plant-available water, which by itself, directly or indirectly depends on several morphological and physical soil properties, as well as on physiographic and land-use factors (Table 3).

A number of physical and hydrological soil indicators are available in order to assess efficiency of restoration activities, such as sustainable land management (SLM) practices. Analyzing the SLM practices documented in the World Overview of Conservation Approaches and Technologies database (WOCAT, 2015) confirms that water is the most common limiting factor for the provisioning service in drylands (Fig. 3). Improving soil moisture through in situ conservation of rainwater or irrigation water often results in increased ecosystem services, like production of food, fodder, fiber, or fuel. Yet, runoff control through SLM practices is also important, not only for increasing water availability, but also for decreasing erosional processes and restoring the water cycle and regulation (e.g., flood control). 
Table 2. Example of soil indicators used in restoration.

\begin{tabular}{|c|c|c|c|}
\hline $\begin{array}{l}\text { Soil } \\
\text { indicator } \\
\text { category }\end{array}$ & Soil indicator & $\begin{array}{l}\text { Relevance to soil processes } \\
\text { and functions }\end{array}$ & Contribution to ecosystem services \\
\hline \multirow{3}{*}{ Physical } & $\begin{array}{l}\text { Infiltration } \\
\text { capacity }\end{array}$ & Runoff/erosion control, leaching & $\begin{array}{l}\text { Soil development/conservation, water purification and } \\
\text { regulation, flood mitigation }\end{array}$ \\
\hline & Topsoil-depth & Rooting volume, habitat for soil fauna & $\begin{array}{l}\text { Carbon sequestration, climate regulation, } \\
\text { biomass production }\end{array}$ \\
\hline & $\begin{array}{l}\text { Macro- } \\
\text { aggregation, } \\
\text { soil structure }\end{array}$ & $\begin{array}{l}\text { Erodibility, nutrient and organic matter } \\
\text { retention, crop emergence }\end{array}$ & $\begin{array}{l}\text { Soil development/conservation, carbon sequestration, } \\
\text { biomass production }\end{array}$ \\
\hline \multirow{4}{*}{ Chemical } & Total nitrogen & Plant and soil fauna development & Biomass production \\
\hline & $\mathrm{pH}$ & $\begin{array}{l}\text { Nutrient availability, pesticide } \\
\text { absorption and mobility }\end{array}$ & Nutrient cycling, biomass production \\
\hline & $\begin{array}{l}\text { Cation } \\
\text { exchange } \\
\text { capacity (CEC) }\end{array}$ & $\begin{array}{l}\text { Plant growth, soil structure, } \\
\text { water infiltration }\end{array}$ & $\begin{array}{l}\text { Nutrient cycling, food and fiber production, } \\
\text { primary production }\end{array}$ \\
\hline & $\begin{array}{l}\text { Electrical } \\
\text { conductivity }\end{array}$ & Soil water potential, salinity & $\begin{array}{l}\text { Water purification and regulation, food and } \\
\text { fiber production, primary production }\end{array}$ \\
\hline Biological & Soil respiration & Biological activity, biomass activity & $\begin{array}{l}\text { Nutrient cycling, water purification and regulation, } \\
\text { pollutants purification }\end{array}$ \\
\hline
\end{tabular}

Rainfall and water availability are a crucial threat in drylands due to scarcity and variability; thus, improving water use efficiency is of the utmost importance. The concept of Green Water Use Efficiency (GWUE), expressed as the fraction of plant transpiration over precipitation (Stroosnijder, 2009), provides a useful indicator in order to evaluate whether the productive water is maximized, while unproductive loss is minimized. Analyses of 30 SLM practices in drylands have revealed that half of these practices produce measurable improvements regarding GWUE (Fig. 4). Detailed knowledge about soil hydrology and hydrological processes allows the effect of land management on blue and green water distribution to be quantified. The concept of blue and green water aims at shifting nonproductive evaporation towards productive transpiration, to improve biomass production without reducing the amount of blue water leaving a watershed. Reducing direct soil evaporation and thereby forcing it to be transpired through the plants is thus one of the key ideas behind turning blue water into green water. Better utilization of rainfall to capitalize on green water requires appropriate land and crop management systems, which can improve water-use efficiency. These can be evaluated again with the GWUE indicator as described above.

Since many physical and hydrological indicators are difficult to quantity, visual soil indicators are getting used instead. These methods include the visual soil assessment, the visual evaluation of soil structure, and the visual assessment of aggregate stability, among others. A recent study by Moncada et al. (2014) demonstrated that visual examinations are reliable semi-quantitative methods to assess soil structural quality and can be considered as visual predictors of soil physical and hydrological properties. 


\subsection{Chemical soil indicators}

Several chemical soil properties may affect and be affected by restoration interventions. The inherent soil fertility is linked to the capacity of the soil to retain and exchange nutrients, a measure of which is the cation exchange capacity (CEC). The CEC is directly related to soil mineral composition, particularly clay content and type, and the soil organic matter content. By increasing the latter, restoration interventions can have a direct impact on soil fertility.

Soil $\mathrm{pH}$ has an important role in restoration planning, as many plants used for restoration purposes have ranges of $\mathrm{pH}$ tolerance. For this reason, soil acidity is generally included in land suitability schemes for either farming or forestry. On the other hand, reducing excessive soil acidity can be a restoration goal. Restoration of acidic soils is an issue also in drylands, where natural acidic soils can be widespread as results of long-term pedogenesis and leaching, or localized, for example, as coastal and inland acid sulfate soils. High acidity is often found in contaminated soils of mining sites, where $\mathrm{pH}$ values can be very low. Restoration of such sites can be particularly challenging, since high acidity and heavy metals' phytotoxicity can combine with soil physical and hydrological inhospitality to target plants (Pellegrini et al., 2016).

Soil alkalinity and salinity are common in degraded drylands, particularly in irrigated lands degraded by inappropriate irrigation practices. Halophyte plants have been successfully used for restoring natural vegetation and/or recovering agricultural productivity in degraded saline and alkaline soils, and also for remediating these soils by actively extracting salt (Hasanuzzaman et al., 2014). On the other hand, contrasting effects were observed in sites located in arid central Morocco where halophyte shrubs (Atriplex nummularia Lindl.) were used to rehabilitate pastures (Zucca et al., 2015a). In this case, besides increasing soil organic matter and water infiltration, the plants have consistently increased the topsoil alkalinity (measured as SAR, or sodium adsorption ratio), showing that possible trade-offs have to be considered. Other restoration practices that imply the application of organic matter such as manures or biosolids might increase soil electric conductivity and affect seedling survival during severe drought years (Fuentes et al., 2010), although this effect also depends on the target species (Oliveira et al., 2011).

\subsection{Soil organic matter}

\section{Soil organic matter and its functional fractions}

Among the several factors of the soil capacity to provide ecosystem services, soil organic matter (SOM) content is considered one of the most important. The main source of SOM is the above- and below-ground residues of vegetation. The humification and decomposition of these organic materials sustains the soil food chain, as the SOM gets utilized as a source of energy for the soil microfauna and mesofauna and fungi. At the same time, mineralization of the plant residues releases nutrients to the soil solution, where they become accessible for uptake by the vegetation's root system.

SOM has a complex nature, and the different forms which result from the humification and decomposition processes have varying residence time in soil (Marschner et al., 2008). However, recent analytical and experimental advances have demonstrated that SOM molecular structure has only a secondary role in controlling its stability, which instead mainly depends on the biotic and abiotic environment (Schmidt et al., 2011). In fact, SOM is subjected to microbial degradation and its persistence can vary depending on both chemical recalcitrance and physical protection. The discrepancy between chemical recalcitrance and residence time can be explained through physical protection mechanisms and physical disconnection between soil organic matter and microorganisms. Physical protection mechanisms can occur at particle-size and aggregate-size levels, through organic carbon sorption on clay particles, as well as inclusion into microaggregates (Chen et al., 2016).

In drylands, the production of biomass, which constitutes the SOM source, is limited by water availability. In general, the size of SOM pools in natural ecosystems decreases exponentially with temperature (Lal, 2004). Consequently most drylands contain $\sim 1 \%$ of SOM, and frequently less than $0.5 \%$. At the same time, the soil smaller moisture content controls decomposition rates, increasing the SOM residence time in drylands. Soils of Mediterranean steppe, for instance, may show a well-developed mollic horizon if they are not plowed (Soil Survey Staff, 1999; Costantini et al., 2013). SOM has an important role in determining the soil physical quality, and therefore, also in regulating the availability of water for vegetation. It impacts soil structure formation, particularly through its positive effects on macroporosity, macroaggregates' formation, and stability. As such, SOM regulates soil water infiltration and retention capacity. In degraded drylands, where plant cover has been disrupted, the input of organic residues into the soil is considerably reduced. Therefore, the susceptibility of degraded drylands to accelerated erosional processes becomes exacerbated, increasing the leakage of organic material and nutrients from the affected ecosystems.

When considering restoration measures for agricultural drylands, the replenishment of soil organic carbon (SOC) pools should be considered as a specific goal. In such environments, where topsoil is thin and poor in organic matter, and highly susceptible to erosion, special attention should be paid to the specific restoration of this uppermost soil layer. Yet, standardized methodologies for assessing the state of SOC depletion are still missing. In addition, besides the overall SOC concentrations and pools, the SOC composition is also important, as it affects its persistence in soil (SOC sequestration) on the one hand, and its availability for decomposition by microbial activity, which determines the soil fertility, on the other hand. 
Table 3. Soil qualities related to plant-available water.

\begin{tabular}{|c|c|c|c|}
\hline Determinants & Drivers & Soil qualities & Functional soil characteristics \\
\hline \multirow[t]{3}{*}{ Water input } & Rainfall, irrigation & Infiltration capacity & $\begin{array}{l}\text { Infiltration rate (texture, structure, } \\
\text { stoniness, cracks) }\end{array}$ \\
\hline & Groundwater & Deep recharge & Capillary rise (texture, structure, stoniness) \\
\hline & $\begin{array}{l}\text { Surface and subsurface } \\
\text { flows }\end{array}$ & Surface recharge & $\begin{array}{l}\text { Topography, natural and artificial } \\
\text { channels, ditches }\end{array}$ \\
\hline \multirow[t]{3}{*}{ Water output } & Evapotranspiration & Surface cover & Mulch, stoniness, crusts \\
\hline & Runoff & Surface morphology & $\begin{array}{l}\text { Slope, mulch, stoniness, rockiness, crusts, } \\
\text { microrelief, natural, artificial channels, ditches }\end{array}$ \\
\hline & $\begin{array}{l}\text { Drainage (rock nature, } \\
\text { artificial piping) }\end{array}$ & Permeability & Hydraulic conductivity \\
\hline \multirow[t]{2}{*}{ Water storage } & Soil volume & Porosity & $\begin{array}{l}\text { Texture, structure, bulk density, stone volume } \\
\text { and weathering }\end{array}$ \\
\hline & & Root penetration & $\begin{array}{l}\text { Root explorable volume of horizon, rooting } \\
\text { depth of profile }\end{array}$ \\
\hline \multirow[t]{2}{*}{ Soil water tension } & Soil water adhesion & $\begin{array}{l}\text { Soil-water-holding } \\
\text { capacity }\end{array}$ & Soil water tension curve \\
\hline & Lithology, irrigation & Salinity & Electrical conductivity, soluble salts \\
\hline \multirow[t]{2}{*}{ Soil water composition } & $\begin{array}{l}\text { Natural background, } \\
\text { pollution }\end{array}$ & Soil water composition & Pollutant content and availability \\
\hline & Anoxia & Oxygen availability & Air capacity \\
\hline
\end{tabular}

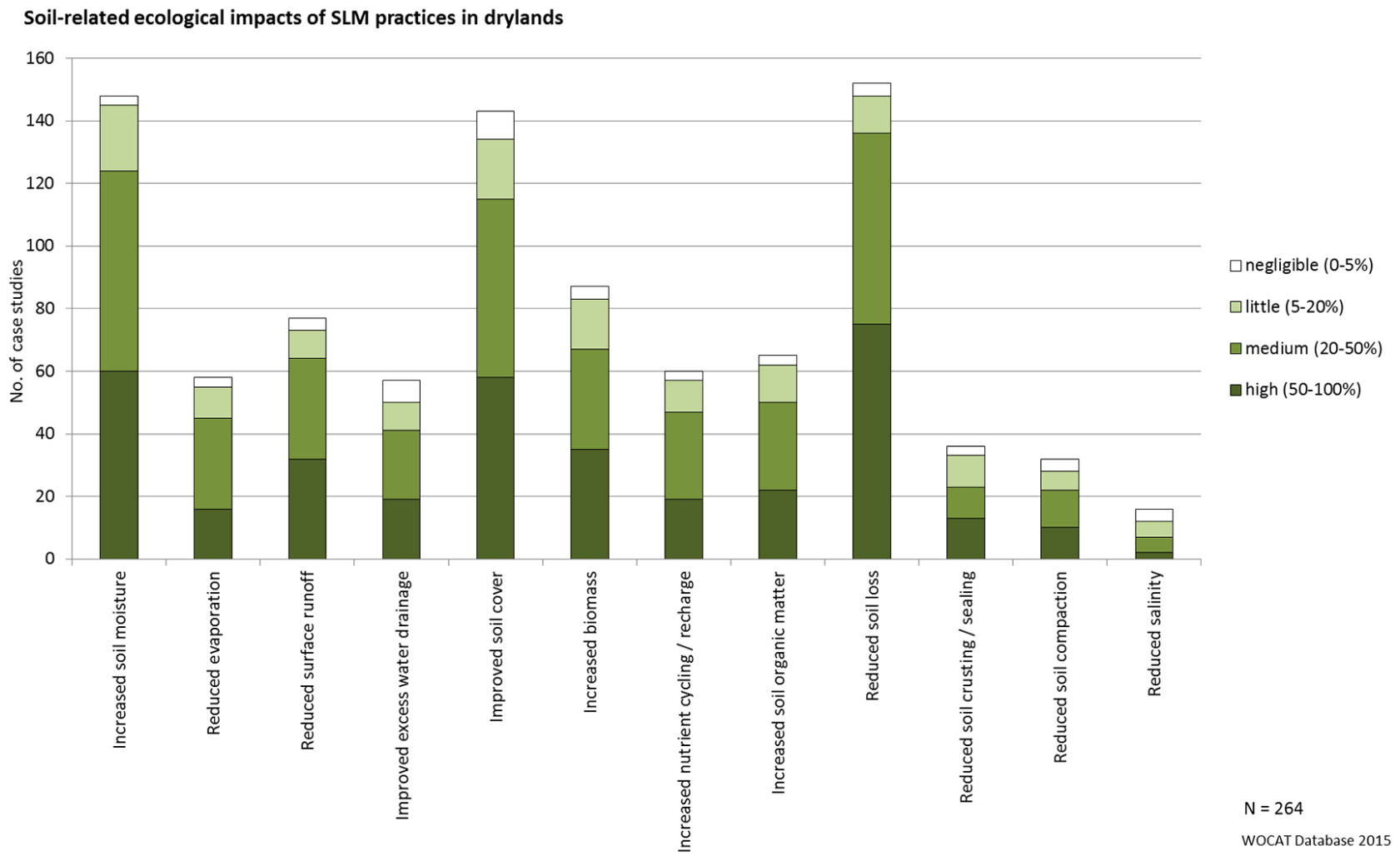

Figure 3. Soil-related ecological impacts of SLM practices in drylands (source: WOCAT, 2015). 
Green Water Use Efficiency

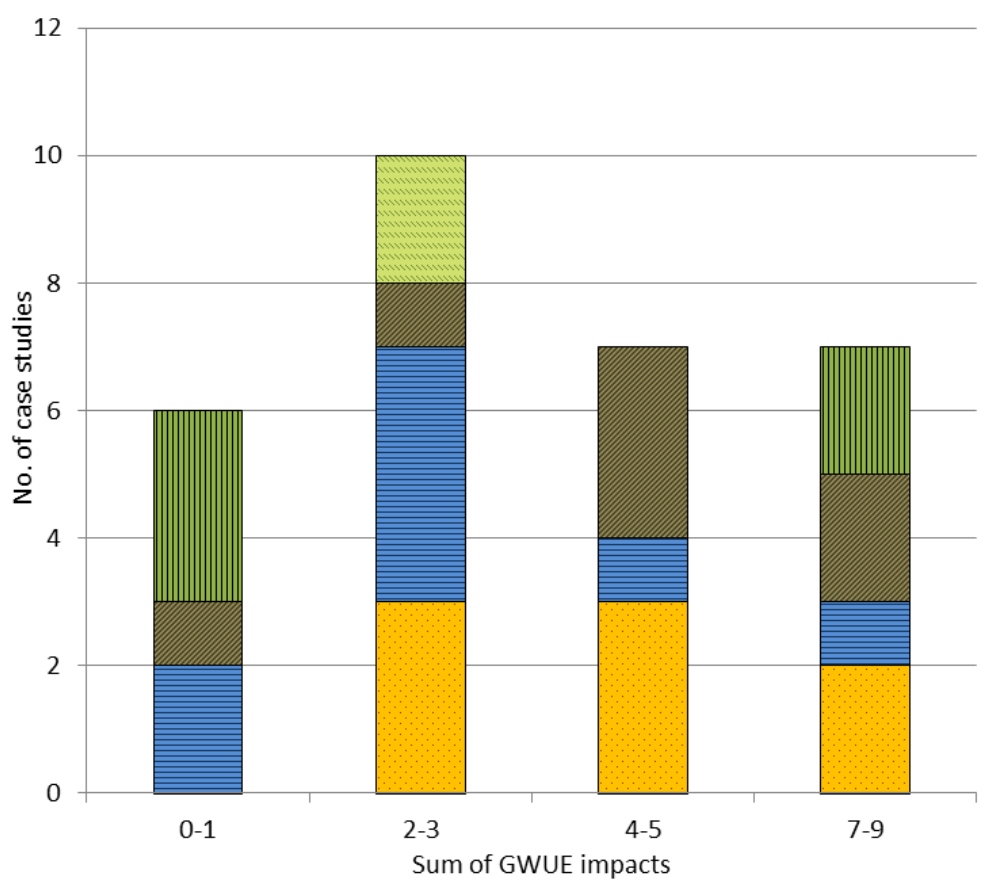

Impacts considered:

- improved soil cover

- reduced soil evaporation

- increased soil moisture

- reduced surface runoff

Impact values:

$1=$ little (5-20\%);

$2=$ medium $(20-50 \%)$;

$3=$ high $(>50 \%)$

\section{m Forest management}

$\square$ Grazing land management

Cross-slope barriers

目Water management

$\square$ Cropping management

Figure 4. Aggregated impacts of SLM practices in regards to Green Water Use Efficiency (source: Schwilch et al., 2014).

SOC is composed of different functional fractions, which are defined according to their persistence capacity (vs. decomposability). The three main groups are (1) the transient fraction, which encompasses the easiest decomposable fraction, such as polysaccharides, with a turnover rate of weeks to months; (2) the temporary fraction, which comprises fine roots and fungal hyphae that are vulnerable to land-use type and management; and (3) the persistent fraction, which includes the most resistant part of SOC, such as humified organic materials. These materials tend to get associated with amorphous iron, aluminum, and aluminosilicates, binding soil particles into microaggregates through clay-polyvalent metal-organic matter complexes, which can last for very long periods of time.

Of the above-mentioned SOC functional fractions, the transient or "active" fraction, which is the most labile organic carbon (LOC) fraction, encompasses only very few percent of the overall SOC pool. However, since the LOC is the most responsive to land-use change and management practices (Fig. 5), it should be considered as a useful indicator of the overall status of soils. Moreover, the measurement of both LOC and total SOC enables the carbon lability $(L)$ to be determined (Blair et al., 1995). $L$ is determined by the following equation:

$$
L=(\mathrm{LOC}) /(\text { total SOC}-\mathrm{LOC})[\% / \%] \text {. }
$$

Three carbon-management-related indices can be utilized for monitoring the impact of land-use change and management practices on the SOC pool. The first is the carbon pool index
(CPI), which indicates the effect of land-use change or management practice on aggradation or degradation of the total SOC, and calculated according to the following equation:

$$
\begin{aligned}
\mathrm{CPI}=\quad & (\text { total SOC in treatment soil }) / \\
& (\text { total SOC in reference soil }) .
\end{aligned}
$$

The second is the lability index (LI), which indicates the ratio between carbon lability in the treatment soil and carbon lability in the reference soil:

$\mathrm{LI}=(L$ in treatment soil $) /(L$ in reference soil $)$.

The third is the carbon management index (CMI), which predicts changes in sequestration and lability of SOC as a result of changes in agricultural practices:

$\mathrm{CMI}=\mathrm{CPI} \times \mathrm{LI}$

An additional advantage of the SOC-management-related indices stems from their standardized (normalized) nature, easing the comparisons among different soils, ecosystems, and biomes, and their ranking according to the state along the degradation-restoration continuum.

Besides concentrations, pools, and composition, another important determinant of SOC is its stratification throughout the soil profile (Franzluebbers, 2002a). The stratification ratio is calculated by the SOC concentration in a shallow depth divided by this in a deeper depth. Overall, in undisturbed soils, a clear stratification occurs, with larger SOC concentrations in shallower layers than in deeper layers. In degraded 


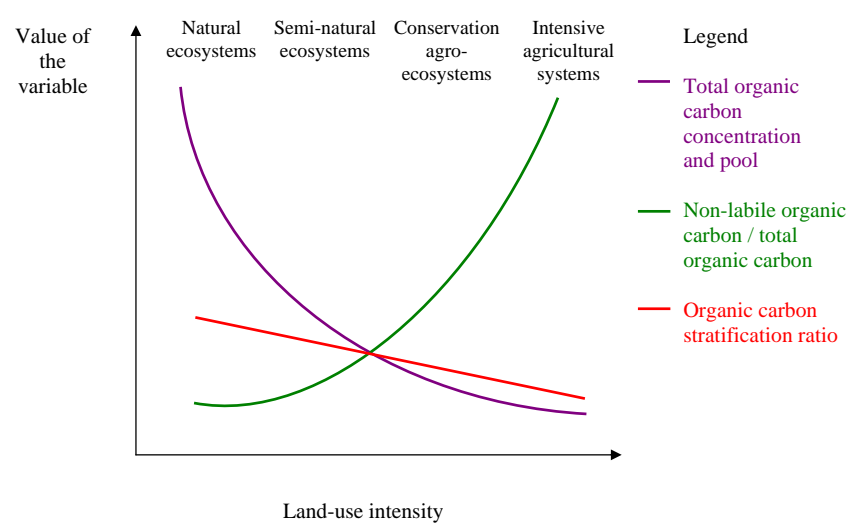

Figure 5. Land-use intensity effects on soil organic carbon dynamics. The $y$ axis is indicative of the increase in the values of the considered variables.

soils, the SOC stratification becomes blurred (Fig. 5), except for some particular cases of hyperarid anthropogenic soils (Camilli et al., 2016). Therefore, if comparing the same soil type, in the same climatic region and biome, and in the same geomorphic unit, the clear stratification of SOC would indicate a better preserved soil profile, while lesser stratified SOC would indicate a certain rate of land degradation. It was suggested that the greater stratification ratio in natural lands stems from the combined effect of accumulation of organic materials on the ground surface, coupled with the undisturbed soil profile. Furthermore, in addition to the total SOC stratification ratio, the stratification of active SOC fractions seems to be even more sensitive to soil degradation (Franzluebbers, 2002b).

\subsection{Soil biochemical and microbiological indicators}

It is well known that the size, composition, and activity of the soil microbial communities may indicate the possible success of restoration of degraded lands, and the impact of management strategies upon them (Harris, 2003). Biological indicators have been widely used to monitor soil quality changes in space and time and to assess biological fertility (Marinari et al., 2010). Most used indicators include microbial biomass carbon, microbial respiration, enzyme activities, and related indices (Table 4) (Kieft et al., 1998; Bastida et al., 2006). Tentative classes of indicators have also been suggested to simplify the estimation of soil biological stress (Benedetti and Mocali, 2008) (Table 5).

A number of selected microbiological indicators are already available for assessing soil functioning (Bloem et al., 2005) which are usually divided into three essential groups, depending on the information they provide, as follows.
1. Soil microbial biomass and number: several conventional methods capable of determining the weight and number of soil microorganisms are based on direct or indirect procedures (Alef and Nannipieri, 1995). The assessment of the total size of the viable microbial community requires culturable cells and comprises the plate count and the most probable number (MPN) techniques. However, about $99 \%$ of soil microorganisms are unculturable (Torsvik et al., 1990). Therefore, biochemical and physiological methods, e.g., chloroform fumigation extraction (Vance et al., 1987) and substrate-induced respiration (SIR) are the most commonly used.

2. Soil microbial activity: the metabolic turnover of the microbial biomass and the conversion of nutrient pools are usually assessed as potential activity, since, to date, no serial and routine methods are available for open field measurements. Potential activity means metabolic activity, including enzymatic activities, that soil microbes are capable of developing under optimal conditions in the laboratory. SOM decomposition is carried out by microorganisms through the enzymatic attack of SOM and microbial respiration: extracellular enzymes degrade SOM through hydrolytic or oxidative processes, producing assimilable dissolved organic matter that can be rapidly incorporated by microbes. Biologically active forms of SOM can function as shortterm indicators of longer term changes in SOM.

3. Soil microbial diversity and community structure: currently, a number of methods are available for the assessment of soil microbial diversity. The use of molecular techniques for investigating microbial diversity of soil communities continues to provide new understanding of soil properties and quality. The analysis of the soil-extracted nucleic acid sequences (DNA and RNA) provides a powerful tool for the characterization of the entire microbial community. It was successfully used even in hypersaline soils of dry areas (Canfora et al., 2014, 2015). The most useful and commonly used methods are those in which small subunit RNA genes are amplified via the polymerase chain reaction (PCR) and analyzed by means of several fingerprinting techniques, such as denaturing gradient gel electrophoresis (DGGE), Terminal Restriction Fragment Length Polymorphysm (T-RFLP), or single-strand conformational polymorphism (SSCP) (Kowalchuk, 2004). Recently, various "omics" approaches have been rapidly advancing in soil science, although they are not ready for widespread adaptation (Myrold and Nannipieri, 2014). Nevertheless, among omics, the metagenomic approach is one of the most promising to simultaneously assess both soil microbial diversity and function (Benedetti and Mocali, 2010). 
Table 4. Biochemical soil attributes.

\begin{tabular}{|c|c|c|}
\hline Name & Code & Unit of measurement \\
\hline Total organic carbon & $\mathrm{C}_{\text {org }}$ & $\mathrm{g} \mathrm{C} \mathrm{kg}^{-1}$ soil \\
\hline Total extractable carbon & $\mathrm{C}_{\mathrm{ext}}$ & $\mathrm{g} \mathrm{C} \mathrm{kg}^{-1}$ soil \\
\hline Humic and fulvic acid carbon & $\mathrm{C}_{\mathrm{ha}}+f_{\mathrm{a}}$ & $\mathrm{g} \mathrm{C} \mathrm{kg}^{-1}$ soil \\
\hline Humification degree & $D_{\mathrm{H}}$ & $\mathrm{mgC}_{\mathrm{ha}}+f_{\mathrm{a}} \mathrm{mg} \mathrm{C}_{\mathrm{ext}}^{-1} \times 100$ \\
\hline Microbial biomass carbon & $\mathrm{C}_{\text {mic }}$ & $\mathrm{mg} \mathrm{C} \mathrm{kg}^{-1}$ soil \\
\hline Basal respiration & $\mathrm{C}_{\text {bas }}$ & $\mathrm{mg} \mathrm{C}-\mathrm{CO}_{2} \mathrm{~kg}^{-1}$ soil \\
\hline $\begin{array}{l}\text { Cumulative respiration, } \mathrm{C}-\mathrm{CO}_{2} \\
\text { total production at } 28 \text { th day }\end{array}$ & $\mathrm{C}_{\text {cum }}$ & $\mathrm{mg} \mathrm{C}-\mathrm{CO}_{2} \mathrm{~kg}^{-1}$ soil \\
\hline Metabolic quotient & $q \mathrm{CO}_{2}$ & $\mathrm{mg} \mathrm{C}-\mathrm{CO}_{2} \mathrm{C}_{\mathrm{mic}}^{-1} \mathrm{~h}^{-1}$ \\
\hline Mineralization quotient & $q \mathrm{M}$ & $\left(\mathrm{C}_{\text {cum }} \mathrm{C}_{\text {org }}^{-1}\right) \times 100$ \\
\hline
\end{tabular}

Table 5. Classes of biological parameters: the lower the class, the higher the soil microbiological stress.

\begin{tabular}{lrrrrr}
\hline Parameters & \multicolumn{5}{c}{ Classes } \\
\cline { 2 - 6 } & 1 & 2 & 3 & 4 & 5 \\
\hline Organic matter (\%) & $<1$ & $1-1.5$ & $1.5-2$ & $2-3$ & $>3$ \\
Basal respiration (ppm) & $<5$ & $5-10$ & $10-15$ & $15-20$ & $>20$ \\
Cumulative respiration (ppm) & $<100$ & $100-250$ & $250-400$ & $400-600$ & $>600$ \\
Microbial biomass carbon (ppm) & $<100$ & $100-200$ & $200-300$ & $300-400$ & $>400$ \\
Metabolic quotient & $>0.4$ & $0.3-0.4$ & $0.2-0.3$ & $0.1-0.2$ & $<0.1$ \\
Mineralization quotient & $<1$ & $1-2$ & $2-3$ & $3-4$ & $>4$ \\
\hline
\end{tabular}

The analysis of types and amounts of different phospholipid fatty acids (PLFAs) is a biochemical approach that offers an alternative to molecular techniques, since it reflects both microbial taxonomic and functional diversity. The amount of total PLFA can be used as an indicator for viable microbial biomass; a further characterization can be done based on specific signature of biomarker fatty acids. Unfortunately, this technique does not include Archaea organisms, since their cell membrane contains ether-linked rather than ester-linked phospholipid fatty acids (Pennanen, 2001). Functional and metabolic features of soil microbial communities have been also analyzed through the assessment of the Communitylevel-physiological profile (CLPP) using Biolog plates (Pignataro et al., 2012).

The future challenges in this research field will be addressed towards standardizing some methodologies, in order to provide quick, reliable, and inexpensive information. All the omics, in particular, have the potential to provide comprehensive and complementary information to traditional techniques, and help monitor changes in soil functions at very detailed spatial and temporal scales.

\subsection{Soil mesofauna}

Beyond the approaches to soil quality evaluation based on the use of physical, chemical, and microbiological indicators, new methods, based on soil mesofauna composition (microarthropods $<2 \mathrm{~mm}$ ), have been proposed for the eval- uation of soil ecosystem services, in particular, biodiversity pools. In fact, soil-dwelling animals have a significant role in the colonization and in the restoration of degraded biological habitats (Starý, 2002); their role includes litter fragmentation, soil aggregation and porosity formation, water infiltration, and distribution of organic matter in soil horizons (Bird et al., 2004). According to Dickinson et al. (2005), soil biodiversity is probably the most important factor for maintaining ecosystem functions in disturbed environments. The higher the number of different mesofauna groups adapted to the soil habitat, the better the soil functionality. Indeed healthy soil systems show a set of ecosystem niches and related organisms, while stressed soils are poorer, both in species and as individuals (Menta et al., 2011). Mesofauna responds to landuse change and management practices and can be considered an efficient bioindicator of ecosystem health (Tizado et al., 2014).

However, one of the main problems related to the bioindices remains in the difficulty of classifying organisms at the species level. For this reason, an approach based on the types of edaphic microarthropods, the QBS-ar (Qualità Biologica del Suolo (Biological Quality of Soil) arthropods) index, has been developed (Parisi et al., 2005). It overcomes difficulties linked to the identification at species level, by focusing on the evaluation of the adaptability to the hypogeal life (Madej et al., 2011). The method itself is rather simple and easy: a soil sample is put in a Berlese-Tullgren extractor 
to collect organisms, which are then observed under a stereomicroscope and identified at the taxonomic level requested by the index. According to the species adaptation to soil environment, a score from 1 to 20 (ecomorphological index) is assigned. The QBS-ar index results from the sum of these scores. Higher values correspond to more complex and soiladapted communities (Mazza et al., 2011). QBS-ar has been applied on a range of soil types and land uses, and its validity was evaluated for assessing soil biodiversity in different settings.

\section{Functional approaches in the monitoring of dryland ecosystems: the Landscape Function Analysis}

Most commonly, mitigation and restoration actions are evaluated by checking vegetation cover and composition. However, functional approaches that also account for the spatial pattern of vegetation, in interaction with the soil nature, seem to be more suited to assess the ecosystem functioning. As previously highlighted, many drylands around the world present a patchy distribution of vegetation following a sink-source spatial pattern. Source areas have a negative balance of resources that accumulate in the sink areas. Beyond this redistribution of resources at the fine scale, a fully functional ecosystem includes the retention within the system. In dry ecosystems, vegetation patchiness can provide a measure of the landscape capacity to conserve water and nutrients (Cerdà, 1997). The assessment of the functionality of these ecosystems should include the description of the spatial distribution of vegetation (size and connectivity of different plant type patches) in combination with soil properties that determine the conservation of resources, especially regarding soil surface attributes. The optimum spatial distribution is both ecosystem-dependent, as the hydrological functioning of plants varies between species, and site-dependent, as resource redistribution at the patch and catchment scale is highly site- and soil-specific; but some attempts have already been done in this regard. Puigdefábregas et al. (1999) suggested that the ratio between sink and source areas in functional ecosystems remains within an optimum range that maximizes functionality. Urgeghe et al. (2010) reported that the collection of runoff by herbaceous patches in a dryland pinyon-juniper ecosystem in southwest USA was maximum when both interpatch bare soil and herbaceous cover were intermediate, suggesting a trade-off between source and sink areas at the finer scale and the existence of herbaceous cover thresholds at the broader catchment scale. Some properties of the sink/source pattern, such as the upslope length and the size of the source area, have been successfully related to the performance of planted seedlings in drylands' restoration actions (Urgeghe and Bautista, 2015).

Landscape Function Analysis (LFA) (Tonway and Hindley, 2004) incorporates both vegetation and soil survey in the evaluation of dryland patchy ecosystems, using functional indicators instead of direct measures of key features. The LFA uses semi-quantitative field-based indicators (Table 6) to evaluate soil surface conditions at the hillslope scale in every identified type of patches and interpatches, targeting surface properties that control stability, nutrient cycling, and infiltration processes. The stability index provides an idea of the vulnerability to erosion and the ability to recover after stresses, the infiltration/runoff index indicates the ratio of rainfall water available to plants and export by runoff, and the nutrient cycling index informs about the in situ recycling of organic matter. For every single type of patch or interpatch, the scores of the quantitative indicators that have an impact on a particular index are summed and referred to the maximum possible score. The final value of the index is calculated by weighing the attained values in all patch and interpatch types by its representativeness in the working area.

Maestre and Puche (2009) observed significant relationships of the indices calculated through LFA with measured soil variables in alpha grass steppes in southeast Spain. These authors found that the infiltration index was positively related to soil-water-holding capacity and negatively to soil compaction, and the nutrient cycling and stability indices were positively related to soil-nutrient variables and microbial activity. However, the sensitivity of the indices might vary depending on the scale and the contrast between different situations.

LFA assessment represents a cheap, rapid, accurate, and repeatable methodology for the evaluation of soil functioning properties, especially in patchy drylands, and it is especially useful as a relative indicator when areas of contrasted histories and disturbance regimes of a similar ecosystem are compared. It has been used, for instance, to monitor the impacts on ecosystem functioning of restoration actions using exotic plant species (Derbel et al., 2009) or fodder shrubs (Zucca et al., 2013b), and also to monitor the effects of grazing and reforestation. LFA infiltration and nutrient cycling indexes have been observed to relate significantly to perennial species richness in Mediterranean drylands (Maestre and Cortina, 2004). In addition, some of the LFA indices, especially infiltration and nutrient cycling, show good correlations with remote sensing indices such as the NDVI (Gaitán et al., 2013). The combination of these two approaches at such different scales may provide useful information on ecosystem functioning and might be a good tool for dryland management by selecting and prioritizing areas to restore.

Besides LFA, there are other possible metrics dealing with the connectivity of water fluxes, bare soil, or interpatch areas, which try to link plant spatial distribution and hydrology. For instance, the Flowlength is a spatially based index that effectively relates the connectivity of source areas and vegetation distribution and topography (Mayor et al., 2008). Borselli et al. (2008) developed a GIS-based connectivity index and a field validation procedure that assesses the links between source and sink areas at the hillslope and landscape 
Table 6. The LFA method (Tongway and Hindley, 2004) uses 13 soil surface field indicators, determined in query zones, and is used to calculate three composite indices (stability, SI; nutrient cycling, NC; infiltration/runoff, IR).

\begin{tabular}{|c|c|c|c|c|c|}
\hline Indicator & Aim and unit of measure & $\begin{array}{r}\text { Number of } \\
\text { classes }\end{array}$ & SI & IR & $\mathrm{NC}$ \\
\hline Rainsplash protection & $\begin{array}{l}\text { Protection offered to soil by perennial vegetation, rocks, } \\
\text { and woody material (as overall \% cover) }\end{array}$ & 5 & $\mathrm{X}$ & & \\
\hline Perennial vegetation cover & $\begin{array}{l}\text { Contribution of below-ground biomass of perennial } \\
\text { vegetation to nutrient cycling and infiltration processes } \\
\text { (estimated as \% canopy cover of perennial plants) }\end{array}$ & 4 & & $\mathrm{X}$ & $\mathrm{X}$ \\
\hline Litter cover & $\begin{array}{l}\text { Contribution of litter material (including ephemeral } \\
\text { herbage such as living annual plants) to nutrient } \\
\text { availability, as \% litter cover plus thickness }\end{array}$ & 10 & $\mathrm{X}$ & $\mathrm{X}$ & $\mathrm{X}$ \\
\hline Litter origin & $\begin{array}{l}\text { Contribution of litter material (including ephemeral } \\
\text { herbage such as living annual plants) to nutrient } \\
\text { availability, with reference to its origin (transported or } \\
\text { local) }\end{array}$ & 2 & & $X$ & $\mathrm{X}$ \\
\hline Litter decomposition & $\begin{array}{l}\text { Contribution of litter material (including ephemeral } \\
\text { herbage such as living annual plants) to nutrient } \\
\text { availability, with reference to its degree of incorporation } \\
\text { to soil }\end{array}$ & 4 & & $X$ & $\mathrm{X}$ \\
\hline Cryptogam cover & $\begin{array}{l}\text { Contribution of algae, fungi, lichens, mosses, and } \\
\text { liverworts to soil surface stability and nutrient } \\
\text { availability, as \% cover of cryptogams visible on the soil } \\
\text { surface }\end{array}$ & 5 & $\mathrm{X}$ & & $\mathrm{X}$ \\
\hline Crust brokenness & $\begin{array}{l}\text { Contribution of soil crust to contain soil loss by erosion } \\
\text { and to increase surface stability, assessed as crust } \\
\text { condition, or brokenness }\end{array}$ & 5 & $X$ & & \\
\hline Erosion type and severity & $\begin{array}{l}\text { Evidence of recent/current erosion processes as } \\
\text { indicator of local instability conditions, as type } \\
\text { (five classes) of process, and its severity (four classes) }\end{array}$ & 20 & $X$ & & \\
\hline Deposited materials & $\begin{array}{l}\text { Presence of material transported from upslope as } \\
\text { indicator of local instability conditions, as \% cover plus } \\
\text { thickness }\end{array}$ & 4 & $X$ & & \\
\hline Surface roughness & $\begin{array}{l}\text { Contribution of soil surface roughness to slow outflow } \\
\text { rates and increase infiltration, as average relief (mm) }\end{array}$ & 5 & & $X$ & $\mathrm{X}$ \\
\hline Surface resistance to disturbance & $\begin{array}{l}\text { Contribution of soil surface resistance to mechanical } \\
\text { disturbance to contain soil loss by erosion, as resistance } \\
\text { of dry soil surface to penetration }\end{array}$ & 5 & $X$ & $X$ & \\
\hline Soil slaking & $\begin{array}{l}\text { Contribution of soil surface stability under rapid } \\
\text { wetting to contain soil loss by erosion, as revealed by } \\
\text { slaking test }\end{array}$ & 5 & $\mathrm{X}$ & $\mathrm{X}$ & \\
\hline Texture & $\begin{array}{l}\text { Role of soil surface texture with regard to surface } \\
\text { permeability, as texture of the } 0-5 \mathrm{~cm} \text { topsoil manually } \\
\text { estimated in the field }\end{array}$ & 4 & & $X$ & \\
\hline
\end{tabular}


scales. The leakiness index by Ludwig et al. (2007) aims at quantifying the ability of the system to retain key resources, such as water and soil, within the system.

\section{Integrated assessment protocols}

Integrated assessment protocols combine field observations of key ecosystem attributes, socioeconomic surveys, and remote sensing (RS)-based geospatial information. Particularly, to conduct the evaluation over wider areas, RS should be employed for land cover change and ecosystems' natural temporal pattern detection, land degradation assessment, and analysis of the impacts of land restoration (Zucca et al., 2015b; Ramos et al., 2015). The quantification of the photosynthetically active herbaceous and shrub biomass production in rangelands and savannahs is one of the most widely used metrics.

Integrated assessment protocols are oriented to more holistically assess the impacts of land management and restoration measures, i.e., to identify their ecological, economic, and sociocultural effects, both over the short term and long term as well as on- and off-site. The WOCAT network (www.wocat.net) has developed such methods in order to document and evaluate SLM technologies and approaches applied in the field. WOCAT is an international network founded in 1992 by land management specialists in order to document and share local sustainable land management practices at the global scale. The methods are internationally standardized and since 2014, have been accredited by the UNCCD as their documentation- and knowledge-sharing platform. The role of science in monitoring and assessing desertification, as well as mitigation/restoration actions, is to produce evidence of their impacts on natural resources and to assess the implications of these impacts on local societies. However, sophisticated and detailed assessment is often expensive and time-consuming and depends on the availability of skilled experts. On the other hand, stakeholder engagement in assessment of indicators is still rare or limited in scope. These are the reasons why a comprehensive but practical assessment tool, like WOCAT is providing, is needed, enabling scientific data to be combined with local experience. In order to evaluate mitigation/restoration practices, performance indicators - e.g., the impact of a given practice on degradation and its economic, ecological, and sociocultural benefits or disadvantages - should be assessed. These are mostly not available quantitatively, but can only be assessed qualitatively by experts, ideally according to predefined response categories (such as "no/negligible" for 0-5, "little" for 5-20, "medium" for 20-50, and "high" for $>50 \%$ of change) in order to ensure comparability over practices, sites, and time. However, where available, quantitative data should be included as well (Schwilch et al., 2011, 2014). Soil- and vegetation-related indicators used in the WOCAT SLM technology questionnaire and assessed in the above described way include soil moisture, evaporation, surface runoff, soil cover, biomass/above-ground $\mathrm{C}$, nutrient cycling, soil organic matter, soil loss, plant diversity, invasive species, beneficial species, etc. Another important aspect is the evaluation of the technical function, such as whether the practice works though an improvement of ground cover, surface roughness, soil structure, water availability, vegetation varieties. Socioeconomic impacts are equally recorded with quantitative and qualitative assessments. These include advantages and disadvantages of the SLM technology regarding, for example, production, income, workload, food security, recreational opportunities, aesthetic and cultural values, community strengthening or conflicts, health. Each SLM technology documented is assessed with the indicators listed and in the way described above. To date, over 500 such SLM technologies have been documented worldwide and are accessible in the WOCAT database (https://qt.wocat.net/qt_report.php).

Based on such assessments, conclusions can be drawn as to whether and how the documented practices address key threats in drylands, i.e., by means of improved water management, reduced soil degradation, diversified and enhanced production, resilience towards climate change and variability, and by providing sociocultural benefits including conflict mitigation and prevention of out-migration (Giger et al., 2015; Schwilch et al., 2014).

\section{Conclusions}

The development of methods for assessing the success of the actions to combat desertification is considered as a priority by the scientific community. The failure of restoration plans is often caused by the choice of plants or practices that are not suited to the site. The success of restoration plans instead relies on a proper and detailed knowledge of the relationships between soil and plant properties and ecology in drylands. One of the main challenges is to select the different species to be used for restoration which have a pattern of the root system matching the horizon characteristics of the soil profile, as well as the specific climate and hydrology of the site. Dryland restoration is a site-specific activity, which implies considering soil spatial and temporal heterogeneity before plant placement. However, ecological restoration of degraded lands is more than the mere recovery of soil ability to support vegetation. In addition to biomass production, restoration strategies should target restoration of ecosystem processes (e.g., nutrient cycling, decomposition), increasing additional ecosystem services such as biodiversity, carbon stock increase, greenhouse gases reduction, flood and sediment regulation, etc.

The understanding of dryland ecosystem processes stems from the very detailed scale of soil observation and analysis. A number of soil indicators support the design of measures and the assessment/monitoring phases. Such soil indicators need to refer to soil properties, which can actually 
be modified through management or restoration activities. Soil organic matter, in particular, is a key attribute for many ecosystem services and one of the main factors affecting water availability in drylands. Soil dynamic properties related to the forms of organic matter, as well as biochemistry, microbiology and mesobiology, are very sensitive to restoration activities. Although the functional forms of soil organic matter and related biological activities and organisms are still not completely understood and characterized, they are promising candidate indicators that may be utilized to assess the effectiveness of restoration strategies in dryland ecosystems.

A recent approach in assessing the effectiveness of restoration strategies in dryland ecosystems is combining the analysis of spatial pattern of vegetation with qualitative soil surface indicators. This simplified but effective methodology, specifically tailored for the surface patterns of drylands, allows the monitoring of landscape functioning variations in space and time, and it is particularly suitable for the assessments carried out at the intermediate territorial scales. On broader scales, effective strategies to combat desertification should be based on integrated biophysical and socioeconomic evaluation methods. Evaluation and monitoring of progress and success are expected to demonstrate the benefits of sustainable management, establish cost-effective thresholds for intervention alternatives, and identify priority areas for action. Recent approaches propose the assessment and evaluation of the effectiveness of management and restoration programs based on indicators that relate to ecosystem integrity and services, but also to socioeconomic and cultural variables associated to human well-being, both over the short term and long term, as well as on- and off-site. To this aim, there is a need for interaction and dialog among the diverse set of scientists and stakeholders involved, which can result in a co-production of new knowledge and, at the same time, in the formulation of new knowledge needs.

Acknowledgements. COST Action ES1104 "Arid Lands Restoration and Combat of Desertification: Setting Up a Drylands and Desert Restoration Hub" is acknowledged for facilitating the establishment of the scientific network which permitted the production of this paper. Special thanks is given to Stefano Mocali, of CREA-ABP, for his useful suggestions and comments on soil biological indicators.

Edited by: A. Cerdà

\section{References}

Alef, K. and Nannipieri, P.: Methods in applied soil microbiology and biochemistry, Academic Press, 1995.

Bastida, F., Moreno, J. L., Hernandez, T., and García, C.: Microbiological degradation index of soils in a semiarid climate, Soil Biol. Biochem., 38, 3463-3473, 2006.

Benedetti, A. and Mocali, S.: Analisi a livello di suolo, Indicatori di biodiversità per la sostenibilità in agricoltura, 159-208, 2008.
Benedetti, A. and Mocali, S.: Exploring research frontiers in microbiology: the challenge of metagenomics in soil microbiology, Res. Microbiol., 161, 497-505, 2010.

Bird, S. B., Coulson, R. N., and Fisher, R. F.: Changes in soil and litter arthropod abundance following tree harvesting and site preparation in a loblolly pine (Pinus taeda L.) plantation, Forest Ecol. Manage., 202, 195-208, 2004.

Blair, G. J., Lefroy, R. D., and Lisle, L.: Soil carbon fractions based on their degree of oxidation, and the development of a carbon management index for agricultural systems, Crop and Pasture Science, 46, 1459-1466, 1995.

Bloem, J., Schouten, A., Sørensen, S. J., Rutgers, M., Werf, A., Breure, A., Hopkins, D., and Benedetti, A.: Monitoring and evaluating soil quality, Microbiological methods for assessing soil quality, Wallingford, CABI Publishing, 23-49, 2005.

Borselli, L., Cassi, P., and Torri, D.: Prolegomena to sediment and flow connectivity in the landscape: a GIS and field numerical assessment, Catena, 75, 268-277, 2008.

Bowker, M. A., Maestre, F. T., Eldridge, D., Belnap, J., CastilloMonroy, A., Escolar, C., and Soliveres, S.: Biological soil crusts (biocrusts) as a model system in community, landscape and ecosystem ecology, Biodivers. Conserv., 23, 1619-1637, 2014.

Brevik, E. C., Cerdà, A., Mataix-Solera, J., Pereg, L., Quinton, J. N., Six, J., and Van Oost, K.: The interdisciplinary nature of SOIL, SOIL, 1, 117-129, doi:10.5194/soil-1-117-2015, 2015.

Calzolari, C., Ungaro, F., Filippi, N., Guermandi, M., Malucelli, F., Marchi, N., Staffilani, F., and Tarocco, P.: A methodological framework to assess the multiple contributions of soils to ecosystem services delivery at regional scale, Geoderma, 261, 190-203, 2016.

Camilli, B., Dell'Abate, M. T., Mocali, S., Fabiani, A., and Dazzi, C.: Evolution of organic carbon pools and microbial diversity in hyperarid anthropogenic soils, J. Arid Environ., 124, 318-331, 2016.

Camprubi, A., Zárate, I. A., Adholeya, A., Lovato, P. E., and Calvet, C.: Field Performance and Essential Oil Production of Mycorrhizal Rosemary in Restoration Low-Nutrient Soils, Land Degrad. Dev., 26, 793-799, 2015.

Canadell, J., Jackson, R., Ehleringer, J., Mooney, H., Sala, O., and Schulze, E.-D.: Maximum rooting depth of vegetation types at the global scale, Oecologia, 108, 583-595, 1996.

Canfora, L., Bacci, G., Pinzari, F., Lo Papa, G., Dazzi, C., and Benedetti, A.: Salinity and bacterial diversity: to what extent does the concentration of salt affect the bacterial community in a saline soil?, PLoS ONE, 9, e106662, doi:10.1371/journal.pone.0106662, 2014.

Canfora, L., Lo Papa, G., Vittori Antisari, L., Bazan, G., Dazzi, C., and Benedetti A.: Spatial microbial community structure and biodiversity analysis in "extreme" hypersaline soils of a semiarid Mediterranean area, Appl. Soil Ecol., 93, 120-129, 2015.

Carpenter, S. R. and Turner, M. G.: Hares and Tortoises: Interactions of Fast and Slow Variablesin Ecosystems, Ecosystems, 3, 495-497, 2000.

Cerdà, A.: The effect of patchy distribution of Stipa tenacissima L. on runoff and erosion, J. Arid Environ., 36, 37-51, 1997.

Chen, X., Duan, Z., and Tan, M.: Restoration Affect Soil Organic Carbon and Nutrients in Different Particle-size Fractions, Land Degrad. Dev., in press, doi:10.1002/ldr.2400, 2016. 
Cortina, J., Maestre, F. T., and Ramírez, D.: Innovations in Semiarid Land Restoration. The case of Stipa tenacissima L. Steppes, Land restoration to combat desertification. innovative approaches, quality control and project evaluation, Fundación CEAM, Valencia Spain, 121-144, 2009.

Costantini, E., L'Abate, G., Faz Cano, A., Mermut, A., Arocena, J., and Ortiz Silla, R.: A Soil Aridity Index to assess desertification risk for Italy, Land degradation and rehabilitation: dryland ecosystems, Papers presented at the Fourth International Conference on Land Degradation, Cartagena, Murcia, Spain, 12-17 September 2004, 231-242, 2009a.

Costantini, E., Urbano, F., Aramini, G., Barbetti, R., Bellino, F., Bocci, M., Bonati, G., Fais, A., L'Abate, G., and Loj, G.: Rationale and methods for compiling an atlas of desertification in Italy, Land Degrad. Dev., 20, 261-276, 2009b.

Costantini, E. A. C., Barbetti, R., Fantappiè, M., L'Abate, G., Lorenzetti, R., and Magini, S.: Pedodiversity, in: The Soils of Italy, edited by: Costantini, E. A. C. and Dazzi, C., World Soils Book Series, Springer, 105-178, 2013.

De la Rosa, D. and Sobral, R.: Soil quality and methods for its assessment, in: Land use and soil resources, Springer, 167-200, 2008.

de Moraes Sá J. C., Séguy L., Tivet F., Lal R., Bouzinac S., Borszowskei P. R., Briedis C., dos Santos J. B., da Cruz Hartman D., Bertoloni C. G., Rosa J., and Friedrich T.: Carbon Depletion by Plowing and its Restoration by No-Till Cropping Systems in Oxisols of Subtropical and Tropical Agro-Ecoregions in Brazil, Land Degrad. Dev., 26, 531-543, 2015.

Derbel, S., Cortina, J., and Chaieb, M.: Acacia saligna plantation impact on soil surface properties and vascular plant species composition in central Tunisia, Arid Land Res. Manag., 23, 28-46, 2009.

Dickinson, N. M., Hartley, W., Uffindell, L. A., Plumb, A. N., Rawlinson, H., and Putwain, P.: Robust biological descriptors of soil health for use in reclamation of brownfield land, Land Contam. Reclam., 13, 317-326, 2005.

Eswaran, H. and Reich, P.: Desertification: a global assessment and risks to sustainability, 16th World Congress of Soil Science: Summaries, 1998.

Franzluebbers, A.: Water infiltration and soil structure related to organic matter and its stratification with depth, Soil Till. Res., 66, 197-205, 2002a.

Franzluebbers, A.: Soil organic matter stratification ratio as an indicator of soil quality, Soil Till. Res., 66, 95-106, 2002b.

Fuentes, D., Valdecantos, A., Llovet, J., Cortina, J., and Vallejo, V. R.: Fine-tuning of sewage sludge application to promote the establishment of Pinus halepensis seedlings, Ecol. Eng., 36, 12131221, 2010.

Gaitán, J. J., Bran, D., Oliva, G., Ciari, G., Nakamatsu, V., Salomone, J., Ferrante, D., Buono, G., Massara, V., and Humano, G.: Evaluating the performance of multiple remote sensing indices to predict the spatial variability of ecosystem structure and functioning in Patagonian steppes, Ecol. Indic., 34, 181-191, 2013.

Giger, M., Liniger, H., Sauter, C., and Schwilch, G.: Economic Benefits and Costs of Sustainable Land Management Technologies: An Analysis of WOCAT's Global Data, Land Degrad. Dev., doi:10.1002/ldr.2429, 2015.
Costantini, E. A. C. (Ed.): Manual of methods for soil and land evaluation. Science Publisher, Enfield (NH), USA, 549 pp., 2009.

Harris, J.: Measurements of the soil microbial community for estimating the success of restoration, Europ. J. Soil Sci., 54, 801808, 2003.

Hasanuzzaman, M., Nahar, K., Alam, M. M., Bhowmik, P. C., Hossain, M. A., Rahman, M. M., Prasad, M. N. V., Ozturk, M., and Fujita, M.: Potential use of halophytes to remediate saline soils, BioMed Research International, 12 pp., 2014.

Hirota, M., Holmgren, M., Van Nes, E. H., and Scheffer, M.: Global resilience of tropical forest and savanna to critical transitions, Science, 334, 232-235, 2011.

Ibáñez, J. J., Zinck, J. A., and Dazzi, C.: Soil geography and diversity of the European biogeographical regions, Geoderma, 192, 142-153, 2013.

Keesstra, S. D., Geissen, V., van Schaik, L., Mosse., K., and Piiranen, S.: Soil as a filter for groundwater quality. Current Opinions in Environmental, Sustainability, 4, 507-516, 2012.

Kieft, T. L., White, C. S., Loftin, S. R., Aguilar, R., Craig, J. A., and Skaar, D. A.: Temporal dynamics in soil carbon and nitrogen resources at a grassland-shrubland ecotone, Ecology, 79, 671683, 1998.

Kowalchuk, G. A.: Molecular microbial ecology manual, Springer Science \& Business Media, p. 1184, 2004.

Kurz-Besson, C., Otieno, D., Do Vale, R. L., Siegwolf, R., Schmidt, M., Herd, A., Nogueira, C., David, T. S., David, J. S., and Tenhunen, J.: Hydraulic lift in cork oak trees in a savannah-type Mediterranean ecosystem and its contribution to the local water balance, Plant Soil, 282, 361-378, 2006.

Lal, R.: Soil carbon sequestration impacts on global climate change and food security, Science, 304, 1623-1627, 2004.

Ludwig, J. A., Bastin, G. N., Chewings, V. H., Eager, R. W., and Liedloff, A. C.: Leakiness: a new index for monitoring the health of arid and semiarid landscapes using remotely sensed vegetation cover and elevation data, Ecol. Indic., 7, 442-454, 2007.

Madej, G., Barczyk, G., and Gdawiec, M.: Evaluation of soil biological quality index (QBS-ar): its sensitivity and usefulness in the post-mining chronosequence-preliminary research, Pol. J. Environ. Stud., 20, 1367-1372, 2011.

Maestre, F. T. and Cortina, J.: Insights into ecosystem composition and function in a sequence of degraded semiarid steppes, Restor. Ecol., 12, 494-502, 2004.

Maestre, F. T. and Puche, M. D.: Indices based on surface indicators predict soil functioning in Mediterranean semi-arid steppes, Appl. Soil Ecol., 41, 342-350, 2009.

Marinari, S., Dell'Abate, M., Brunetti, G., and Dazzi, C.: Differences of stabilized organic carbon fractions and microbiological activity along Mediterranean Vertisols and Alfisols profiles, Geoderma, 156, 379-388, 2010.

Marschner, B., Brodowski, S., Dreves, A., Gleixner, G., Gude, A., Grootes, P. M., Hamer, U., Heim, A., Jandl, G., and Ji, R.: How relevant is recalcitrance for the stabilization of organic matter in soils?, J. Plant Nutr. Soil Sc., 171, 91-110, 2008.

Mayor, Á. G., Bautista, S., Small, E. E., Dixon, M., and Bellot, J.: Measurement of the connectivity of runoff source areas as determined by vegetation pattern and topography: a tool for assessing potential water and soil losses in drylands, Water Resour. Res. 13, W10423, doi:10.1029/2007WR006367, 2008. 
Mazza, G., Agostini, N., Aquiloni, L., Carano, G., Inghilesi, A., Tricarico, E., and Gherardi, F.: The indigenous crayfish Austropotamobius pallipes complex in a national park of Central Italy, Knowl. Manag. Aquat. Ec., 24, 1-12, 2011.

Menta, C., Leoni, A., Gardi, C., and Conti, F. D.: Are grasslands important habitats for soil microarthropod conservation?, Biodivers. Conserv., 20, 1073-1087, 2011.

Moncada, M. P., Penning, L. H., Timm, L. C., Gabriels, D., and Cornelis, W. M.: Visual examinations and soil physical and hydraulic properties for assessing soil structural quality of soils with contrasting textures and land uses, Soil Till. Res., 140, 20-28, 2014.

Myrold, D. D. and Nannipieri, P.: Classical techniques versus omics approaches, Omics in soil Science, edited by: Nannipieri, P., Pietramellara, G., and Renella, G., Caster Academic Press, Norfolk, UK, 179-187, 2014.

Oliveira, G., Nunes, A., Clemente, A., and Correia, O.: Effect of substrate treatments on survival and growth of Mediterranean shrubs in a revegetated quarry: an eight-year study, Ecol. Engin., 37, 255-259, 2011.

Parisi, V., Menta, C., Gardi, C., Jacomini, C., and Mozzanica, E.: Microarthropod communities as a tool to assess soil quality and biodiversity: a new approach in Italy, Agriculture, Ecosys. Environ., 105, 323-333, 2005.

Pellegrini, S., Garcia, G., Penas-Castejon, J. M., Vignozzi, N., and Costantini, E. A. C.: Pedogenesis in mine tails affects macroporosity, hydrological properties, and pollutant flow, Catena, 136, 3-16, 2016.

Pennanen, T.: Microbial communities in boreal coniferous forest humus exposed to heavy metals and changes in soil $\mathrm{pH}-\mathrm{a}$ summary of the use of phospholipid fatty acids, Biolog ${ }^{\circledR}$ and 3 $\mathrm{H}$-thymidine incorporation methods in field studies, Geoderma, 100, 91-126, 2001.

Pignataro, A., Moscatelli, M. C., Mocali, S., Grego, S., and Benedetti, A.: Assessment of soil microbial functional diversity in a coppiced forest system, Appl. Soil Ecol., 62, 115-123, 2012.

Príncipe, A., Nunes, A., Pinho, P., do Rosário, L., Correia, O., and Branquinho, C.: Modeling the long-term natural regeneration potential of woodlands in semi-arid regions to guide restoration efforts, Europ. J. Forest Res., 133, 757-767, 2014.

Puigdefábregas, J., Solé, A., Gutiérrez, L., del Barrio, G., and Boer, M.: Scales and processes of water and sediment redistribution in drylands: results from the Rambla Honda field site in southeast Spain, Earth Sci. Rev., 48, 39-70, 1999.

Ramos, A., Pereira, M. J., Soares, A., do Rosário, L., Matos, P., Nunes, A., Branquinho, C., and Pinho, P.: Seasonal patterns of Mediterranean evergreen woodlands (Montado) are explained by long-term precipitation, Agr. Forest Meteorol., 202, 44-50, 2015.

Roa-Fuentes, L. L., Martínez-Garza, C., Etchevers, J., and Campo, J.: Recovery of Soil C and $\mathrm{N}$ in a Tropical Pasture: Passive and Active Restoration, Land Degrad. Dev., 26, 201-210, 2015.

Salvati L. and Bajocco S.: Land sensitivity to desertification across Italy: Past, present, and future, Appl. Geogr., 31, 223-231, 2011.

Schenk, H. J. and Jackson, R. B.: Rooting depths, lateral root spreads and below-ground/above-ground allometries of plants in water-limited ecosystems, J. Ecol., 90, 480-494, 2002a.

Schenk, H. J. and Jackson, R. B.: The global biogeography of roots, Ecol. Monogr., 72, 311-328, 2002b.

Schmidt, M. W., Torn, M. S., Abiven, S., Dittmar, T., Guggenberger, G., Janssens, I. A., Kleber, M., Kögel-Knabner, I., Lehmann, J., and Manning, D. A.: Persistence of soil organic matter as an ecosystem property, Nature, 478, 49-56, 2011.

Schwilch, G., Bestelmeyer, B., Bunning, S., Critchley, W., Herrick, J., Kellner, K., Liniger, H., Nachtergaele, F., Ritsema, C., and Schuster, B.: Experiences in monitoring and assessment of sustainable land management, Land Degrad. Dev., 22, 214-225, 2011.

Schwilch, G., Liniger, H., and Hurni, H.: Sustainable land management (SLM) practices in drylands: how do they address desertification threats?, Environ. Manage., 54, 983-1004, 2014.

Silva, J. S., Rego, F. C., and Martins-Loução, M. A.: Belowground traits of mediterranean woody plants in a portuguese shrubland, Ecologia Mediterranea, 28, 5-13, 2002.

Smith, P., Cotrufo, M. F., Rumpel, C., Paustian, K., Kuikman, P. J., Elliott, J. A., McDowell, R., Griffiths, R. I., Asakawa, S., Bustamante, M., House, J. I., Sobocká, J., Harper, R., Pan, G., West, P. C., Gerber, J. S., Clark, J. M., Adhya, T., Scholes, R. J., and Scholes, M. C.: Biogeochemical cycles and biodiversity as key drivers of ecosystem services provided by soils, Soil, 1, 665-685, doi:10.5194/soil-1-665-2015, 2015.

Soil Survey Staff: Soil Taxonomy: A basic system of soil classification for making and interpreting soil surveys, 2nd Edn., USDA-NRCS, Agricultural Handbook 436, US Gov. Print. Office, Washington DC USA, 869 pp., 1999.

Starý, J.: Changes of oribatid mite communities (Acari : Oribatida) during primary succession on colliery spoil heaps near Sokolov, Norh-West Bohemia, Czech Republic, Studies on Soil Fauna in Central Europe, České Budějovice, ISB, ASCR, 199-206, 2002.

Stroosnijder, L.: Modifying land management in order to improve efficiency of rainwater use in the African highlands, Soil Till. Res., 103, 247-256, 2009.

Tizado, E. J. and Núñez-Pérez, E.: Terrestrial arthropods in the initial restoration stages of anthracite coal mine spoil heaps in northwestern spain: Potential usefulness of higher taxa as restoration indicators, Land Degrad. Dev., doi:10.1002/ldr.2280, 2014.

Toktar, M., Papa, G. L., Kozybayeva, F. E., and Dazzi, C.: Ecological restoration in contaminated soils of Kokdzhon phosphate mining area (Zhambyl region, Kazakhstan), Ecol. Engin., 86, 14, 2016.

Tonway, D. and Hindley, N.: Landscape Function Analysis: procedures for monitoring and assessing landscapes with special reference to Minesite and Rangelands, CSIRO Australia, 2004.

Torsvik, V., Goksøyr, J., and Daae, F. L.: High diversity in DNA of soil bacteria, Appl. Environ. Microbiol., 56, 782-787, 1990.

Urgeghe, A. M. and Bautista, S.: Size and connectivity of upslope runoff-source areas modulate the performance of woody plants in Mediterranean drylands, Ecohydrology, 8, 1292-1303, 2015.

Urgeghe, A. M., Breshears, D. D., Martens, S. N., and Beeson, P.C.: Redistribution of runoff among vegetation patch types: on ecohydrological optimality of herbaceous capture of runon, Rangeland Ecol. Manag., 63, 497-504, 2010

Uribe, D., Geneletti, D., del Castillo, R. F., and Orsi, F.: Integrating stakeholder preferences and GIS-based multicriteria analysis to identify forest landscape restoration priorities, Sustainability, 6, 935-951, 2014.

Vance, E., Brookes, P., and Jenkinson, D.: An extraction method for measuring soil microbial biomass C, Soil Biol. Biochem., 19, 703-707, 1987. 
WOCAT: WOCAT Database: Technology, ttp://cdewocat.unibe.ch/ wocatQT/index.php, 2015.

Wong, J. T.-F., Chen, X. -W., Mo, W. -Y., Man, Y. -B., Ng, C. W.-W., and Wong, M.-H.: Restoration of Plant and Animal Communities in a Sanitary Landfill: A 10-year Case Study in Hong Kong, Land Degrad. Dev., doi:10.1002/ldr.2402, 2015.

Yi, X. and Wang, L.: Land Suitability Assessment on a Watershed of Loess Plateau Using the Analytic Hierarchy Process, PloS One, 8, e69498, doi:10.1371/journal.pone.0069498, 2013.

Zucca, C., Bautista, S., Orr, B., and Previtali, F.: Desertification: prevention and restoration, in: Encyclopedia of Environmental Management, vol. I, edited by: Jorgensen, S. E., Taylor \& Francis, New York, 594-609, 2013a.
Zucca, C., Pulido-Fernández, M., Fava, F., Dessena, L., and Mulas, M.: Effects of restoration actions on soil and landscape functions: Atriplex nummularia L. plantations in Ouled Dlim (Central Morocco), Soil Till. Res., 133, 101-110, 2013 b.

Zucca, C., Arrieta Garcia, S., Deroma, M., and Madrau, S.: Organic Carbon and Alkalinity Increase in Topsoil After Rangeland Restoration Through Atriplex nummularia Plantation, Land Degrad. Dev., doi:10.1002/ldr.2378, 2015a.

Zucca, C., Wu, W., Dessena, L., and Mulas, M.: Assessing the Effectiveness of Land Restoration Interventions in Dry Lands by Multitemporal Remote Sensing - A Case Study in Ouled DLIM (Marrakech, Morocco), Land Degrad. Dev., 26, 80-91, 2015 b. 